\title{
Partisan, scholarly and active: arguments for an organic public sociology of work
}

Paul Brook, University of Leicester, UK

Ralph Darlington, University of Salford, UK

\begin{abstract}
Despite a thriving tradition of critical scholarship in UK-based sociology of work, Burawoy's call for a partisan organic public sociology that is part of 'a social movement beyond the academy' and Bourdieu's plea for committed scholarship in the service of the social movement against neo-liberalism have received scant attention. This article seeks to stimulate debate by presenting a framework for a left-radical organic public sociology of work based on Gramsci's concept of the connected organic intellectual rather than Bourdieu's expert committed scholar. The latter, it is argued, is incompatible with activist partisan scholarship based on democratised relations between researchers and researched. Participatory Action Research is offered as a methodological orientation that underpins and enables organic scholars of work to engage actively with the marginalised and labour in the co-creation of knowledge that aids their struggles for change.
\end{abstract}

\section{Key Words}

organic public sociology of work - organic intellectual - Participatory Action Research Gramsci - Bourdieu - committed scholar - critical realism 


\section{Introduction: calls for action}

As capitalist crisis, resistance to austerity and political polarization intensifies in Europe, Burawoy's high-profile call in 2005 for an organic public sociology in which the 'sociologist as partisan' defends the 'social' and 'represents humanity' in an era of 'market tyranny and state despotism' (2007: 55) appears evermore relevant. It echoes Bourdieu's own call of the late 1990s for 'scholarship with commitment' (2003: 17), 'useful to the social movement' opposing neo-liberalism (1998: 58). While Burawoy's plea sparked an extensive, sometimes heated, debate about the efficacy of scholarly partisanship and activism (see Clawson et al, 2007), it is strange that apart from a few exceptions (see Heery, 2012; Stewart and Lucio, 2011, Watson, 2010) partisan public sociology has not been debated amongst UK-based scholars of work. This is especially paradoxical given Burawoy's own prominence as a labour process sociologist and the UK's influential traditions of critical scholarship that to varying degrees pursue open partisanship on the side of those subordinated in the labour process and marginalised in the labour market (see Thompson, 2010; Stewart and Lucio, 2011).

This article aims to stimulate debate amongst scholars of work and employment on the feasibility and desirability of a left-radical ${ }^{1}$ organic public sociology of work in which the researcher is overtly partisan and active on the side of the marginalised and labour. We argue that Gramsci's notion of the organic intellectual rather than Bourdieu's committed scholar offers a more robust and politically compatible model for researchers wanting to engage actively with the marginalised and labour in their struggles. We then discuss how the concept of the organic intellectual finds contemporary expression in the established methodological tradition of Action Research, especially its emancipatory-oriented variant, Participatory Action Research (PAR). By drawing on PAR's practices and critical realism's materialist 
epistemology, partisan organic scholars can ensure their research is rigorous, valid and representative through being reflexive, accountable to agents and relevant to their struggles. The article concludes by briefly considering what should and could comprise a vibrant leftradical organic public sociology of work. We stress the need to expand and deepen existing organic public sociology so that it encompasses not only organised labour but also helps to give voice to the unorganised, vulnerable and unwaged.

\section{From criticality to partisanship}

In one sense all scholarship is partisan and committed (Bourdieu, 2003; Heery, 2012), as it is inevitably filtered through the scholar's 'personal lens that is situated in a specific sociopolitical and historical moment' (Cresswell, 2003: 182). These lenses are invariably premised on a range of assumptions about the efficacy, desirability or harm of socio-economic phenomena. To be critical, however, is not necessarily to engage in partisan scholarship, although criticality clearly underpins it (Hammersley, 1999, Watson, 2010). The key question is the degree to which the scholar goes beyond using their work to critique conservative, common-sense knowledge and socio-economic domination (Burawoy, 2007) to ally openly with a social group or cause, thereby engaging in an 'oppositional form of critical study' (Watson, 2010: 926).

In order to draw out the distinction between criticality and partisanship, Burawoy's (2007) argument for organic public sociology offers a useful framework. For him, the core questions are 'for whom and for what do we pursue sociology?' (2007: 34) In answering, he locates himself in a long-standing sociological tradition committed to partisan scholarship, whose champion, Wright Mills (1959), argued that an intellectual's role is the creation of an informed and radical public that challenges the powerful and generates political action to 
transform society. Similarly, Burawoy argues that public sociology's engagement with extraacademic audiences should be about striking up '... a dialogic relation between sociologist and public in which the agenda of each is brought to the table, in which each adjusts to the other' (2007: 34) in an on-going debate about fundamental values and desired outcomes. Thus, organic public sociology is defined as critical scholarship that focuses beyond the academy and engages actively with external social agents, movements and organisations. One notable example in recent years is Ehrenreich's bestselling Nickel and Dimed: Undercover in Low-Wage USA (2002).

\section{Bourdieu's committed scholar or Gramsci's organic intellectual?}

Stewart and Lucio (2011) have recently used Bourdieu's notion of committed scholarship to underpin and justify their call for a new politics of research engagement that seeks to democratise relations with, and break down barriers between, scholars and the researched, to enable 'in a critical, sociological way, the active voices of the marginalised and their collective views' to be heard (2011: 332). The issue of democratising research engagement is a prime example of how partisan researchers have to be 'aware of the effects that their work has on the world, and seek to bring these under ethical and political control as well' (Hammersley, 1999: 3). However, the extent to which this is possible hinges as much on the the researcher's epistemological position as it does on an ideological commitment to participative democracy. This is crucially illustrated by the contrasting politicised epistemologies of the two leading models for left-radical partisan research: Bourdieu's committed scholar and Gramsci's organic intellectual (Burawoy, 2012; Callinicos, 1999; MacKinnon, 2009). 
Despite the enormous contribution of Bourdieu's ideas and public activism to harnessing researchers to the cause of social movements, the notion of the committed scholar (and associated collective intellectual ${ }^{2}$ ) is incompatible with the notion of democratising relations between the researcher and the researched. For Bourdieu, the weight of symbolic domination in capitalist society is so great that its victims inescapably internalise the discourses of the powerful (doxa) that mystify understanding of their exploitation and oppression. This then ensures submission to the established order, which manifests itself through individuals' cultural countenance, behaviours and attitudes (habitus) (Eagleton, 1992). The political consequence is that 'with the masses imprisoned in doxa, the intellectual becomes the indispensable bearer of critique' (Callinicos, 1999: 100).

The implication of Bourdieu's (1999) theory is that only suitably qualified scholars can provide effective critique of the dominant neo-liberal discourses. This is because empirical research involves social relationships with agents whose ideas are suffused with doxa. Accordingly, when the researcher connects closely with the researched their dialogue is frequently so distorted by doxa that it produces 'sociolinguistic data, incapable of providing the means of interpretation', even after the researcher attempts to 'construct this discourse scientifically' (Bourdieu, 1999: 611-612). Therefore, valid interpretation can only come from the expert intellectual who occupies a separate epistemological space from the social movement activist, thereby not 'forsaking her exigencies and completeness as a researcher' (Bourdieu, 2003: 18). Nevertheless, the expert committed scholar working for social movements still needs to be vigilant against doxa's distorting mystification through selfcritical reflexivity, which is the 'absolute prerequisite to any political action by intellectuals' (2003: 19). 
A social movement's functional relationship to a committed scholar, therefore, is akin to that of a client to a professional service, albeit one where the researcher shares the former's political commitment. This epistemological separation finds explicit political expression in Raison d'Agir's (2012) formal distinction between 'intellectual and organizational forms of resistance'. The implication of this separation is that there is no space or forum outside of established intellectual-academic practice, such as within movement organisations, where political discourse and analysis by all active participants can generate an organic and equally rigorous rationality (Burawoy, 2005; Callinicos, 1999). Consequently, the call by Stewart and Lucio (2011: 339) for a 'new methodology of engagement' is incompatible with Bourdieu's theoretical and political underpinning of the committed scholar.

By contrast, Gramsci's (1971) notion of the organic intellectual does offer the basis for a non-elitist, democratic methodology of engagement between the researcher and the researched. For Gramsci, intellectual activity is common to the human condition as each person possesses an implicit philosophical position in the form of a general belief system and opinions (Ives, 2004), albeit one founded on a contradictory tension between the ruling class' ideological common sense and experientially derived good sense (Gramsci, 1971; Ives, 2004). Accordingly, Gramsci's starting-point is that '[a]11 men are intellectuals... but not all men have in society the function of intellectuals' (1971: 9). Therefore, categories of official intellectuals, such as academic scholars, should not be defined by their scholarly activity and privileged access to truth or reason but by their functional organisation as a distinct social group within the ensemble of capitalist social relations. For Gramsci, intellectuals do not necessarily 'possess higher intelligence or profundity or even a greater ability to reason per se'; rather their distinctiveness arises from performing a very different specialist function compared to other people (Ives, 2004: 75). The capacity to think and reason soundly, 
therefore, is not confined to professional academic intellectuals. Every social group can possess its own 'particular specialized category of intellectuals' (Gramsci, 1971: 7), such as political parties and social movements' internal theorists and writers.

Gramsci's argument that each social group can produce its own intellectuals allows him to posit a fundamental distinction between traditional and organic intellectuals. He argues that traditional intellectuals are those that present themselves 'as autonomous and independent of the dominant social group' (1971: 7) but effectively function as an intellectual for the dominant social group (Mackinnon, 2009), as with the example of Anthony Giddens' public interventions in support of the Third Way and the New Labour ideological project (Burawoy, 2005; Callinicos, 1999). Conversely, organic intellectuals are rooted in, and bound to, a specific social group. This is created through an interrelationship between the perceived effectiveness of the intellectual's ideas, in giving voice to the agents, and their active affiliation to the social group (see Connolly, 2010; Darlington, 2009). Significantly for Gramsci, the relationship is deepened through the intellectual's direct involvement in visible counter-hegemonic struggle on the side of agents against the ruling ideological common sense, such as during protest campaigns and industrial action. This in turn nurtures the emergence of other organic intellectuals from within and encourages traditional intellectuals, such as academic scholars, to seek organic relationships with the subaltern group.

The organic intellectual relates to subaltern groups not as an autonomous tribune but as the intellectual manifestation of their collective voice in counter-hegemonic struggle. Thus, the organic intellectual's role can be that of strategist, leader, spokesperson and educator, working side-by-side with and within the subaltern group (MacKinnon, 2009). It is a relationship where organically forged ideas and political struggle are 'caught up in a constant 
dialogue in which intellectual practice, rather than belonging to the exclusive domain of cultural production, is, through its integration into broader political activity, continually put to the test and thereby critically scrutinized and revised' (Callinicos, 1999: 101). For the organic intellectual - and contrary to Bourdieu's concept of the committed scholar - there is not a wall of expertise separating the scholar's craft from the ideas of the marginalised and labour. For while Gramsci (1971) recognises the valuable contribution of rigorous, formal scholarship, its practice and organisation assumes an ultimately illusory autonomy of the researcher that unwittingly reproduces the inequalities and elitism of capitalism.

\section{From organic intellectual to organic public sociology}

Burawoy argues that organic public sociology $(2005 ; 2012)$ should be founded on the notion of the sociologist as an organic intellectual rather than on Bourdieu's committed scholar engaged in loosening the stranglehold of doxa. This is because in the final analysis truth is only accessible in continual dialogue with agents themselves through which it can be forged into a counter-hegemonic discourse that challenges the common-sense of the powerful. Thus, he follows Gramsci's understanding that while members of subaltern groups are subject to dominant ideologies (common sense) this never totally eclipses their indigenous reason (good sense), arising from their lived experience of inequality and subordination. It is this good sense that organic intellectuals should excavate and elaborate in a committed partnership with agents. Hence, social change for Burawoy arises from intellectuals working in close connection with the marginalised, 'elaborating local imaginations of what could be, and struggling for their realisation' (2005: 430).

Stewart and Lucio (2011) make a similar case when they argue that the partisan researcher in taking on the role of elaborating the views and pursuing the goals of marginalised agents 
helps to offset the unequal resources available to them compared to managers and state officials. In Gramscian terms, it is an example of counter-hegemonic struggle but for the researcher's work to be accepted by agents', as their authentic voice and politically valuable, requires the forging of an organic connection between both parties. This is principally achieved through the researcher actively participating in the agents' struggle, which in turn empowers them to make politico-scholarly interventions from within (see Connolly, 2010) and even in the name of the movement, campaign or organisation (see Fantasia, 1988). In the process, methodological relations begin to be democratised thereby challenging the illusory notion of scholarly autonomy. Thus, the role of the organic researcher is to break down the barriers to become part of the agents' solution through a less hierarchical, more democratic process built on a shared active commitment rather than stand apart as a neutral observer on the pedestal of professional integrity.

No matter how credible the argument for organic public sociology from a left-radical perspective a common criticism is that a politicisation of sociology will undermine intellectual rigour and its accompanying reputation for impartiality and objectivity (see Clawson et al, 2007). It is a persistent criticism, despite defenders of partisan research highlighting the paradox of traditional policy research's assumed impartiality and objectivity, while being inherently partisan due to its objectives being set by an often powerful client, such as government or business (Burawoy, 2007; Heery, 2012; Stewart and Lucio, 2011). Nevertheless, advocates of partisan research do acknowledge that there is a necessity to maintain a critical distance from agents to avoid the danger of wrongly asserting political faith over contrary evidence (Siraj-Blatchford, 1995). For Burawoy (2005), the safeguard lies in researcher reflexivity, as it does for Bourdieu's committed scholar (1999; 2003). 
In qualitative research, especially ethnography, reflexivity is a crucial dimension (Cresswell, 2003; Denis and Lehoux, 2009), requiring the researcher to be as transparent about the process and their role as possible. This is because it is not possible to be neutral and therefore it is important for the researcher to be open about their ideological position (Reid and Frisby, 2008). The degree of reflexivity is also important. For organic public sociology, it is vital that the researcher not only acknowledges their situated position but critically explores their social and political impact on the social subject of the research (Denis and Lehoux, 2009; Reid and Frisby, 2008). In this way, there is an open, reflexive and dialogical commentary by the researcher on the interrelationship between their rigorous application of data collection methods, ideological commitment and active support for subaltern interests (MacKinnon, 2009). However, while reflexivity enjoys widespread acceptance as a methodological procedure, it continues to be criticised for being overly subjective, untestable and insufficiently transparent, especially in relation to underpinning claims for objectivity in oppositional partisan research (see Hammersley, 1999). There is also the perennial risk of research being stigmatised as political activism rather than scholarship. For example, Beynon's (1973/1984) Working for Ford was condemned by Ford management for its 'doubtful value as an objective sociological study' on the basis that 'Beynon comes so much to identify himself with the stewards', but was defended by stewards as an authentic portrayal of life in a car factory (Beynon, 1973/1984: 11-15). How then can organic researchers strengthen their credibility by ensuring that their data is valid and representative beyond extolling rigorous self-critical practice (Siraj-Blatchford, 1995)?

\section{Organic intellectuals and Participatory Action Research}

The Action Research tradition offers an established methodological orientation (Reason and Bradbury, 2008) that can frame the practice of organic public sociology and help to 
strengthen its claims to legitimacy within the academy and beyond. This is because action research is oriented on creating organisational/social change with agents rather than for them (Denis and Lehoux, 2009). This is done by seeking 'to create participative communities of inquiry'... [through]... a practice of participation, engaging those who might otherwise be subjects of research or recipients of interventions to a greater or lesser extent as coresearchers' (Reason and Bradbury, 2008: 1). Given this orientation on participation, active agents and social change, it is surprising that action research has had modest take-up in industrial relations and sociology of work (Huzzard and Björkman, 2012), despite both containing vibrant labour-oriented traditions (Heery, 2012; Thompson, 2010).

Huzzard and Björkman (2012) argue that action research with unions and workplace actors in general should comprise a deeper form of collaborative research (see Denis and Lehoux, 2009) with a 'much stronger emphasis on both action and collaboration' (p. 163). Significantly, this enhanced emphasis corresponds with the principles of the organic intellectual (Mackinnon, 2009), as researching with agents means research in action, rather than being about action. This involves 'a collaborative democratic partnership' with agents at every stage of the research process, ensuring that knowledge outcomes are co-produced (Huzzard and Björkman, 2012: 163-164).

While we support Huzzard's and Björkman's (2012) understanding of action research, they omit its widely-held emancipatory principle. As Reason and Bradbury (2008: 5) explain, action research 'without its liberating and emancipatory dimension is a shadow of its full possibility and will be in danger of being co-opted by the status quo'. Those working within the action research umbrella tradition (see Reason and Bradbury, 2008: 7-8) wanting to emphasise its emancipatory dimension have in response developed Participatory Action 
Research (PAR) (Kemmis, 2006). PAR is a critical approach that focuses on 'democratizing the research process, acknowledging lived experiences and contributing to social justice agendas to counter prevailing relations that are deeply gendered, classed and racialized' (Reid and Frisby, 2008: 93).

How then does PAR (and action research generally) ensure scholarly rigour and the validity of its knowledge outcomes in terms of practical relevance to agents? While reflexivity is axiomatic, the process undergoes a qualitative transformation from being an individual researcher's subjective commentary and analysis into a collectivised, democratic process with agents. Corresponding to PAR's principles of co-operative participation, the researcher's committed engagement from the outset should be marked by a continuous, interactive reflexivity framed by accountable, democratised relations with agents. In other words, a researcher's organic connections to agents entails forging an interdependent relationship between co-researchers, comprising continual collective critical reflection and open debate in their shared pursuit of organisational/social change (Denis and Lehoux, 2009; Reid and Frisby, 2008).

In many PAR settings, such as social movements, campaigns and unions the research process and outcomes are likely to be subject to the organisation's own democratic procedures and practices (Denis and Lehoux, 2009). However, in politically contested settings, such as unions and large campaign organisations, the researcher must continually navigate a complex organisational terrain and guard against the undermining of inclusive participation and critical distance (Huzzard and Björkman, 2012). Nevertheless, to be organic requires active engagement in internal political debates (Clawson, 2011), as to do otherwise is to distance oneself from the social group's intellectual engine. The extent to which this is possible 
depends on the nature of the planned intervention and with whom (formal leaders and/or ordinary activists). It is also determined by the extent to which the researcher is organically pre-connected, such as being an established activist, having a prior research relationship or a history of related interventions and valued publications whereby their politics and affiliations are already known.

Ultimately, PAR seeks to confront and combine the separation of formal knowledge from experiential knowledge through co-operation (Denis and Lehoux, 2009), which inevitably means that there are increased methodological tensions, especially around ensuring critical distance (see Huzzard and Björkman, 2012; 167-168). Nevertheless, engagement through cooperation offers rich advantages in broadening and deepening the reach of sociology of work, not least in privileging the voice of the marginalised, exploited and oppressed. PAR, as with organic public sociology generally, cannot rely on traditional positivistic forms of procedural rigour to be judged as valid and representative, as this would deny its principles of organic connectedness and co-operative knowledge creation. Instead, there has to be a high degree of ethical-political judgement (Huzzard and Björkman, 2012; Reid and Frisby, 2008; Watson, 2010) born of exhaustive self and collective reflexivity (Denis and Lehoux, 2008). However, this judgement should be continually debated and amended through thick accountable relations with agents - and ultimately with external others via academic and public debate.

Inherent to a researcher's ethical-political judgement is their underpinning epistemological position. As Hammersley (1999) argues, what constitutes objectivity is an epistemological question, which is ultimately a political judgement. This is evident in Gramsci's Marxism in which the subaltern's experientially derived good sense is of raised epistemological significance, as it offers enhanced understanding of structural inequalities, exploitation and 
oppressive social relations, thereby informing activity for social change (Burawoy, 2005; Callinicos, 1999). From a feminist perspective, Reid and Frisby (2008: 98) similarly privilege the perspective of oppressed women when they argue that it is necessary 'to connect the articulated and the contextualised personal with the often hidden or invisible structural and social institutions that shape and define our lives'. This form of emancipatory 'standpoint epistemology' (Hammersley, 1999: 6) provides an alternative version of methodological objectivity that privileges the experiences and ideas of the marginalised, exploited and oppressed in order to improve knowledge of their relationship to underlying structures of subordination, as a means to better challenge them.

Related to 'standpoint epistemology' is the emergence of critical realism, as an increasingly influential philosophical and critical research tradition in the sociology of work, including much Marxist and other left-radical scholarship (Fleetwood and Ackroyd, 2004). For critical realism, social reality is layered, comprising deep and emergent structures in an interdependent relationship with social agency that in turn generates social change (Ackroyd, 2009). Its epistemological concern is to produce theory that accurately identifies causal mechanisms in social change. Like organic public sociology, critical realism understands that good knowledge has to be both meaningful to actors and provide understanding of their active impact in social relations and on structures, such as workplaces and labour markets. As with PAR, critical realism stresses that the test of knowledge is its practical adequacy as explanation and as a guide to achieving social change by its users (Fleetwood and Ackroyd, 2004). While critical realism is a broad research tradition, encompassing a range of progressive political orientations (see Watson, 2010), it provides additional epistemological underpinning to organic public sociology's emphasis on thick engagement with actors and social change. 
Critical realism argues for a broad range of methods drawing on multiple data, often through case studies. However, due to quantitative research's ontological assumptions of a flat, unlayered reality directly accessible by observation, critical realism argues that its role should be limited to supportive, descriptive statistics (Ackroyd, 2009). For critical realism, quantitative research on its own is unable to capture the dynamic and contingent interplay of structure and agency, particularly the significance of the relationship between agents meaning, their activity and social change. When this is combined with quantitative research's notion of rigour, as the avoidance of bias through operational detachment, it is a methodological approach that eschews organic engagement and limits collaboration with agents (Denis and Lehoux, 2009). However, for Bourdieu's expert committed scholar, the role of quantitative research is ambiguous, even if he rejects 'positivism's dream of an epistemological state of innocence' (1999: 608).

\section{Conclusion: towards an organic public sociology of work}

The ebb and flow of struggle 'from below' obviously affects the opportunities for organic public sociology. As the tide of struggle against neo-liberal austerity rises, with its accompanying political fracturing and polarisation, especially in Europe, the questions of with whom and for whom we do sociology are increasingly relevant. Related to these is the question of what type of sociology, as we argue in our critique of Bourdieu's committed scholar and our advocacy of Gramsci's organic intellectual. This leaves the question of what left-radical organic public sociology of work should and could consist of.

Organised labour is the most immediately accessible and fertile location for organic public sociology (Burawoy, 2005), especially during industrial action (see Connolly 2010; 
Darlington, 2012; Fantasia, 1988). Indeed, there already exists the UK-based Critical Labour Studies (2011) group of academics (and a minority of activists) committed to working with labour in struggle and pursuing radical-socialist politics inside the labour movement. However, a left-radical organic public sociology of work should be much broader than organised labour, even if opportunities to work with activists in struggle are few amongst the unorganised, vulnerable and unwaged. Working with them to articulate and advocate their interests is also an important dimension to organic public sociology, such as Hardy et al's (2010) studies of sex workers, even if there is only minimal collective organisation and resistance or no immediate prospect of it.

More problematic is how to take organic public sociology into the public realm. While some texts reach a wider audience than the academy, such as Beynon's Working for Ford (1973/1984) and Hochschild's The Managed Heart (1983/2003), they are rare exceptions. Rarer still are bestselling publications written as popular sociologies of work. Two of the most successful recent examples are Ehrenreich's (2002), Nickel and Dimed: Undercover in Low-wage USA and Standing's (2011), The Precariat: The New Dangerous Class, both of which generated major public debates through extensive media coverage. Just occasionally, sociologists of work can intervene in a struggle with significant results. During the British Airways cabin crew dispute of 2009-10, 100 academics signed a letter, published in The Guardian (25 March, 2010), condemning the company's stance and tactics, resulting in senior executives making multiple media appearances to counter its claims. Equally, organic public sociology should also address issues that emanate 'from above' and affect the world of work. For example, using the mass media (and social media) whenever possible to counter neo-liberal analysis of the economic crisis and its avowal of austerity or translating equality law developments into politico-intellectual resources for social movements (Conley, 2012). 
While big media interventions and bestselling popular sociologies of work are uncommon, they demonstrate what is possible, particularly when we organise collectively. More importantly, they need to be recognised as the tip of the organic public sociology iceberg. Below the surface, we should extend and deepen our organic engagement with the organised, unorganised, marginalised and unwaged, whether they are in overt struggle or searching for their voices to be heard, as a first step in pursuing social change.

Finally, we also recognise it is not just methodological and political-ethical questions that need addressing but also how to build a more vibrant and effective left-radical organic public sociology of work in contemporary higher education, when confronted by intensifying marketization, restrictive research assessment metrics and funding austerity, not least in the UK. In particular, the UK's current mechanism for periodically measuring performance and allocating public research funding, the Research Excellence Framework (REF), now explicitly assesses excellence against the criterion of whether research produces 'any social, economic or cultural impact or benefit beyond academia' (REF2014, 2011: 4). Despite appearances, this is far from an official endorsement of public sociology. Instead, it expresses the state's formal favouring and rewarding of policy relevant research that is inevitably dominated by the powerful (and lucrative) demands of business and the state's marketoriented policy agenda. The consequence is an erosion of academics' autonomy (through institutional support and public funding) (UCU, 2009) to pursue emancipatory-oriented research that is critical of capital, the market and neo-liberal austerity (Smith, 2010). We believe there is much to consider and debate. 


\section{Notes}

${ }^{1}$ We define left-radical as Marxist, other anti-capitalist and anti-oppression/emancipatory perspectives.

2 See Raison d'Agir (2012), an organisation of intellectuals committed to social justice founded with Bourdieu in 1998.

\section{References}

Ackroyd, S (2009)'Research designs for realist research' in D.A. Buchanan and A. Bryman (eds.) The Sage Handbook of Organizational Research Methods, London: Sage, pp. 532-548.

Beynon, H (1984) Working for Ford, Harmondsworth: Penguin.

Bourdieu, P (1998) Acts of Resistance, Cambridge: Polity.

Bourdieu, P (1999) The Weight of the World, Cambridge: Polity.

Bourdieu, P (2003) Firing Back: Against the Tyranny of the Market 2, London: Verso.

Burawoy, M (2005) 'Response: Public sociology: populist fad or path to renewal?', The British Journal of Sociology, 56(3): 417-432.

Burawoy, M (2007) 'For public sociology' in D. Clawson, R. Zussman, J. Misra, N. Gerstel, R. Stokes, D.L. Anderton, and M. Burawoy (eds.) Public Sociology, London: University of California, pp. 23-66. 
Burawoy, M (2012) 'The roots of domination: beyond Bourdieu and Gramsci', Sociology, 46(2): 187-206.

Callinicos, A (1999), 'Social theory put to the test of politics: Pierre Bourdieu and Anthony Giddens', New Left Review, 236: 77-102.

Clawson, D (2011) 'It's an academic question: why progressive intellectuals should not stay out of internal union battles', New Labor Forum, 20(2): 9-12.

Clawson, D, Zussman, R, Misra, J, Gerstel, N, Stokes, R, Anderton, D.L, and Burawoy, M (eds.) (2007) Public Sociology, London: University of California.

Conley, H (2012) 'Using equality to challenge austerity: new actors, old problems' Work, Employment and Society, 26(2): 349-359

Connolly, H (2010) Renewal in the French Labour Movement: A Grassroots Perspective, Oxford: Peter Lang.

Cresswell, JW (2003) Research Design: Qualitative, Quantitative and Mixed-methods Approaches, London: Sage.

Critical Labour Studies (2011) Available at www.criticallabourstudies.org.uk (accessed 17 October). 
Darlington, R (2009) 'Leadership and Union Militancy: The Case of the RMT', Capital and Class, 33 (3): 3-32.

Darlington, R (2012) 'The Interplay of Structure and Agency Dynamics in Strike Activity', Employee Relations, forthcoming 34 (5).

Denis, J-L and Lehoux, P (2009) 'Collaborative research: renewing action and governing science' in DA Buchanan and A Bryman (eds.) The Sage Handbook of Organizational Research Methods, London: Sage, pp. 363-380.

Eagleton, T (1992), 'Doxa and common life: in conversation with Pierre Bourdieu', New Left Review, 191: 111-121.

Ehrenreich, B (with Toynbee, P) (2002) Nickel and Dimed: Undercover in Low-wage USA, London: Granta.

Fantasia, R (1989) Cultures of Solidarity: Consciousness, Action and Contemporary American Workers, Berkeley: University of California Press.

Fleetwood, S and S Ackroyd, (eds), (2004) Critical Realist Applications in Organisation and Management Studies, London: Routledge.

Gramsci, A (1971) Selections from Prison Notebooks, London: Lawrence and Wishart. 
Hammersley, M (1999) Taking Sides in Social Research: Essays on Partisanship and Bias, London: Routledge.

Hardy, K, Kingston, S and Sanders, T (eds.) (2010) New Sociologies of Sex Work, London: Ashgate.

Heery, E (2012) 'Partisan frames: analysing partisanship within industrial relations', paper presented to International Labour and Employment Relations Association World Congress, Philadelphia, PA.

Hochschild, AR (1983/2003) The Managed Heart: Commercialization of Human Feeling, London: University of California.

Huzzard, T and Björkman, H (2012) 'Trade unions and action research', Work, Employment and Society 26(1): 161-171.

Ives, P (2004) Language and Hegemony in Gramsci, London: Pluto Press.

Kemmis, S (2006) 'Participatory action research and public sphere', Educational Action Research 14(4): 459-476.

MacKinnon, S (2009) 'Social work intellectuals in the twenty-first century: critical social theory, critical social work and public engagement', Social Work Education 28(5): 512-527.

Mills, CW (1959) The Sociological Imagination, Oxford University Press. 
Raison d'Agir (2012) Available at http://www.homme-moderne.org/raisonsdagir-editions/. (accessed on 22 April).

Reason, P and Bradbury, H (eds.) (2008) 'Introduction' to Sage Handbook of Action Research, London: Sage, pp. 1-11.

REF2014 (2011) 'Decisions on assessing research impact', Bristol: hefce.

Reid, C and Frisby, W (2008) 'Continuing the journey: articulating dimensions of feminist participatory research (FPAR), in P Reason and H Bradbury (eds.) Sage Handbook of Action Research, London: Sage, pp. 93-105.

Siraj-Blatchford, I (1995) 'Critical social research and the academy: the role of organic intellectuals in educational research', British Journal of Sociology of Education, 16(2): 205220.

Smith, K (2010) 'Research, policy and funding - academic treadmills and the squeeze on intellectual spaces', The British Journal of Sociology, 61(1): 176-195.

Standing, G (2011) The Precariat: The New Dangerous Class: London: Bloomsbury.

Stewart, P and Lucio, MM (2011) 'Collective narratives and politics in the contemporary study of work: the new management practices debate', Work, Employment and Society, 25(2): $327-341$. 
Thompson, P (2010) 'The capitalist labour process: concepts and connections', Capital and Class 34(1): 7-14.

UCU (2009) 'Response to the Research Excellence Framework: second consultation on the assessment and funding of research', London: University and College Union.

Watson, TJ (2010) 'Critical social science, pragmatism and the realities of HRM', International Journal of Human Resource Management 21(6): 915-931.

Title of submission: Partisan, Scholarly and Active: Arguments for An Organic Public Sociology of Work

\section{Biographies}

Paul Brook is a senior lecturer in Sociology of Work and Employment at the University of Leicester. He has published in the areas of emotional labour, labour power and labour process theory. He is an Associate Editor for the International Journal of Management Concepts and Philosophy and was secretary of the British Universities Industrial Relations Association (BUIRA) from 2007-10.

Ralph Darlington is Professor of Employment Relations at Salford University. He has written extensively on trade union organisation and activity in both historical and contemporary contexts and is the author of The Dynamics of Workplace Unionism (London, 1994), The 
Political Trajectory of J.T. Murphy (Liverpool, 1998), Glorious Summer: Class Struggle in Britain, 1972 [with Dave Lyddon] (London, 2001), and Syndicalism and the Transition to Communism: An International Comparative Analysis (Aldershot, 2008). He also edited What's the Point of Industrial Relations?: In Defence of Critical Social Science (Manchester, 2009). 